\title{
Analysis of Chemical Composition Homogeneity in the Cross-section of the Rods Produced from Alloys of 6xxx Group
}

\author{
Analiza homogenosti kemijske sestave po preseku litih drogov \\ izdelanih iz zlitin iz skupine $6 \mathrm{xxx}$
}

\author{
Maja Vončina ${ }^{1, *}$, Peter Cvahte², Ana Kračun², Tilen Balaško', Jožef Medved' \\ ${ }^{1}$ Faculty of Natural Sciences and Engineering, Department for Materials and Metallurgy, University of Ljubljana, \\ Ljubljana, Slovenia \\ ${ }^{2}$ Impol Group, Partizanska 38, 2310 Slovenska Bistrica, Slovenia \\ * maja.voncina@omm.ntf.uni-lj.si
}

\begin{abstract}
The alloys from Al-Mg-Si system provide an excellent combination of mechanical properties, heat treatment at extrusion temperature, good weldability, good corrosion resistance and formability. Owing to the high casting speed of rods or slabs, the solidification is rather non-equilibrium, resulting in defects in the material, such as crystalline segregations, the formation of low-melting eutectics, the unfavourable shape of intermetallic phases and the non-homogeneously distributed alloying elements in the cross-section of the rods or slabs and in the entire microstructure. The inhomogeneity of the chemical composition and the solid solution negatively affects the strength, the formability in the warm and the corrosion resistance, and can lead to the formation of undesired phases due to segregation in the material. In this experimental investigation, the cross-sections of the rods from two different alloys of the $6 x x x$ group were investigated. From the cross-sections of the rods, samples for differential scanning calorimetry (DSC) at three different positions (edge, D/4 and middle) were taken to determine the influence of inhomogeneity on the course of DSC curve. Metallographic sample preparation was used for microstructure analysis, whereas the actual chemical composition was analysed using a scanning electron microscope (SEM) and an energy dispersion spectrometer (EDS).
\end{abstract}

Key words: casted rods for extrusion, homogeneity of chemical composition, DSC analysis, microstructure.

\section{Povzetek}

Zlitine iz sistema Al-Mg-Si zagotavljajo odlično kombinacijo mehanskih lastnosti, toplotno obdelavo pri temperaturi ekstruzije, dobro varivost, dobro korozijsko odpornost in preoblikovalnost. Zaradi visoke hitrosti ulivanja drogov ali bram je strjevanje dokaj neenakomerno, kar ima za posledico nastanek napak v materialu, kot so kristalne segregacije, tvorba nizkotaljivih evtektikov, neugodna oblika intermetalnih faz in nehomogena porazdelitev legirnih elementov po preseku drogov ali bram in v celotni mikrostrukturi. Nehomogenost kemične sestave in trdne raztopine negativno vpliva na trdnost, preoblikovalnost $\mathrm{v}$ toplem ter korozijsko odpornost, poleg tega pa lahko vodi do tvorbe nezaželenih faz zaradi segregacije v materialu. $\mathrm{V}$ tej eksperimentalni preiskavi smo preučili preseka drogov dveh različnih zlitin iz skupine 6xxx. Vzorci za diferencialno vrstično kalorimetrijo (DSC) so bili odvzeti iz prečnega prereza droga na treh različnih mestih (rob, D/4 in sredina), z namenom ugotavljanja vpliva nehomogenosti na potek DSC krivulje. Za analizo mikrostrukture smo uporabili metalografski vzorec, medtem ko smo dejansko kemijsko sestavo analizirali z energijsko disperzijskim spektrometrom (EDS) na vrstičnem elektronskem mikroskopu (SEM).

Ključne besede: liti drogovi za ekstrudiranje, homogenost kemične sestave, DSC analiza, mikrostruktura.

Ә Open Access. ( 2019 Vončina M., Cvahte P., Kračun A., Balaško T., Medved J., published by Sciendo. (cc) Br-Nc-ND This work is licensed under the Creative Commons Attribution-NonCommercial-NoDerivatives 4.0 License. 


\section{Introduction}

Aluminium alloys from the group 6xxx have good mechanical properties, good formability and corrosion resistance. Alloyed elements affect weldability, corrosion resistance, corrosion cracking, electrical conductivity and density. Alloying magnesium and silicon to aluminium alloys from the group 6xxx takes place in the appropriate ratio $(\mathrm{Mg} / \mathrm{Si}=1.73)$ to form the $\mathrm{Mg}_{2} \mathrm{Si}$ phase [1]. In practice, alloys of the $6 \mathrm{xxx}$ system produced by casting techniques containing excess silicon or magnesium. Excess silicon results in higher strength and increases their transformability but reduces corrosion resistance. Excess magnesium increases corrosion resistance but reduces transformability and strength $[2,3]$.

The presence of iron in alloys of the 6xxx system results in the formation of phases such as $\mathrm{Al}_{3} \mathrm{Fe}, \mathrm{Al}_{8} \mathrm{Fe}_{2} \mathrm{Si}, \mathrm{Al}_{8} \mathrm{FeMg}_{3} \mathrm{Si}_{6}$ and $\mathrm{Al}_{6} \mathrm{Fe}$, which may be detrimental to the properties of these alloys [4]. Iron reduces ductility and toughness by forming coarse components with aluminium and other alloying elements. It also reduces strength, corrosion resistance and fatigue resistance. The alloying elements of chromium and manganese correct the shape and size of iron phases and its compounds in alloys of the 6xxx system. The presence of manganese not only increases the temperature of recrystallisation and corrosion resistance but also allows dispersion hardening and ageing [2].

Although alloys from the group 6xxx have lower strength than alloys from the groups 2xxx and $7 \mathrm{xxx}$, they have advantages such as good formability and corrosion resistance. Bismuth and lead can also be added for better machining by cutting. These alloys are used for profiles for doors, windows, ladders, walls and fences. They are used for the manufacture of frames for motors and cabinets of electric motors, heating and cooling pipes, office equipment, etc. [5].

The production of products from the alloys of the group 6xxx begins with the continuous or semi-continuous casting of the rods, followed by homogenisation. With a higher degree of homogenisation, better formability properties can be expected, which are crucial for further processing. Homogenisation annealing is the process by which crystal segregations and low-melting eutectics are eliminated, the shape of intermetallic phases is changed and small precipitates are formed. The homogenisation process achieves a uniform distribution of the alloying elements throughout the entire microstructure. The inhomogeneity of the solid solution can adversely affect the corrosion/oxidation resistance, strength, working temperature (consequence of artificial reduction of melting point in interdendritic spaces) and formability in a warm, and can cause undesired phases due to segregation [6, 7]. Thus, by means of homogenisation annealing, the formability of bars, ingots and other cast semi-finished products is improved; in this case, casted rods made of aluminium alloys, since they have non-homogeneously distributed alloying elements throughout the microstructure [8-10].

The uneven distribution of alloying elements inside the dendritic microstructure is a feature of high cooling rates. These differences increase with increasing cooling rates and greater differences in the composition between the melt and the solid phases at the beginning of crystallisation, which in some alloys can only be equated with long-term homogenisation as a result of solid-phase diffusion processes [11-13].

Owing to the non-equilibrium solidification, in the solid state, eutectic can be obtained, which according to the theoretical phase diagram should not form. Lowering the temperature at which incipient fusion started is so called a non-equilibrium solidus (NRS). In order to avoid local incipient fusion, each heat treatment must be carried out below the NRS temperature. Local incipient fusion may result in the formation of porosity resulting from the dissolution of non-equilibrium phases. The cracks formed during the forming can be the result of a molten eutectic phase that does not dissolve.

The degree of inhomogeneity is influenced by several different factors. The wider interval of solidification of the individual alloy in practical and theoretical aspects contributes to greater non-homogeneity. The increase in non-homogeneity is also influenced by the difference in the size of the solvent atoms and dissolved atoms, and their crystalline structure $[5,11]$.

The homogenisation annealing of cast structures to improve the formability was developed on the basis of empirical methods for determin- 
ing the time and temperature of the annealing. One of the determining factors is diffusion. In the empirical determination of the time and temperature of the annealing, the diffusivity of the local chemical composition must be taken into account. The diffusion of individual particles can be used to approximately determine the diffusion time, for which the following expression (1) can be used: $[8,10]$.

$\sim \frac{x^{2}}{D}$

In this equation $x$ is the diffusion path and represents half of the space between the secondary dendritic arms. Therefore, the process of homogenisation is more effective if the grains are smaller, since the elements need to take a shorter path. $D$ represents the diffusivity given in the following equation, whereas $D_{0}$ represents diffusion constant; $Q$ is the activation energy for the diffusion; $R$ is a gas constant and $T$ is the temperature at which diffusion takes course.

$D=D_{0} \exp \left(\frac{-Q}{R T}\right)$

According to this equation, the temperature has an exponential influence on the diffusion and consequently also on the time and temperature of homogenisation. By homogenisation annealing, only micro-segregation can be influenced. By the solidification of large castings, macro-segregations may occur, which may also be one metre high and could not be affected by homogenisation annealing [11].

In Table 1 , the calculation of the diffusion coefficients of the various elements and the time needed at the certain temperature at which the element travels $50 \mu \mathrm{m}$ (the hypothetical half-distance between the secondary dendritic arms) are given. Table 1 shows that the time drastically reduces with the rising temperature. Among the selected elements, the longest diffusion times are for manganese, where at a temperature of $600^{\circ} \mathrm{C}$, the homogenisation annealing should last as much as for $567.3 \mathrm{~h}$. Among other elements, only iron is also more difficult, which requires $21.6 \mathrm{~h}$ at the same temperature, while for other elements, the diffusion at a distance of $50 \mu \mathrm{m}$ takes place in $2.2 \mathrm{~h}(\mathrm{Cu}), 2.1 \mathrm{~h}$ (Al - self - diffusion), $0.7 \mathrm{~h}(\mathrm{Si}), 0.5 \mathrm{~h}(\mathrm{Mg})$ and $0.3 \mathrm{~h}(\mathrm{Zn})$ [14-17].
Table 1: Diffusion of elements in aluminium at temperatures 550,600 and $650^{\circ} \mathrm{C}$ at a distance of $50 \mathrm{~mm}[14-17]$.

\begin{tabular}{|c|c|c|c|}
\hline Element & $\mathrm{T}\left[{ }^{\circ} \mathrm{C}\right]$ & $D\left[\mathbf{c m}^{2} / \mathbf{s}\right]$ & $t[\mathbf{h}]$ \\
\hline \multirow{3}{*}{$\mathrm{Al}$} & 550 & $9.64 \mathrm{E}-10$ & 7.2 \\
\hline & 600 & 3.32E-09 & 2.1 \\
\hline & 650 & $9.98 \mathrm{E}-09$ & 0.7 \\
\hline \multirow{3}{*}{$\mathrm{Fe}$} & 550 & $6.70 \mathrm{E}-11$ & 103.6 \\
\hline & 600 & $3.22 \mathrm{E}-10$ & 21.6 \\
\hline & 650 & $1.30 \mathrm{E}-09$ & 5.3 \\
\hline \multirow{3}{*}{$\mathrm{Si}$} & 550 & $3.21 \mathrm{E}-09$ & 2.2 \\
\hline & 600 & $1.04 \mathrm{E}-08$ & 0.7 \\
\hline & 650 & $2.95 \mathrm{E}-08$ & 0.2 \\
\hline \multirow{3}{*}{$\mathrm{Mg}$} & 550 & 4.30E-09 & 1.6 \\
\hline & 600 & $1.31 \mathrm{E}-08$ & 0.5 \\
\hline & 650 & $3.55 \mathrm{E}-08$ & 0.2 \\
\hline \multirow{3}{*}{$\mathrm{Mn}$} & 550 & $2.01 \mathrm{E}-12$ & 3461.6 \\
\hline & 600 & $1.22 \mathrm{E}-11$ & 567.3 \\
\hline & 650 & $6.14 \mathrm{E}-11$ & 113.1 \\
\hline \multirow{3}{*}{$\mathrm{Cu}$} & 550 & $9.83 \mathrm{E}-10$ & 7.1 \\
\hline & 600 & 3.15E-09 & 2.2 \\
\hline & 650 & 8.88E-09 & 0.8 \\
\hline \multirow{3}{*}{$\mathrm{Zn}$} & 550 & 7.30E-09 & 1.0 \\
\hline & 600 & $2.00 \mathrm{E}-08$ & 0.3 \\
\hline & 650 & 4.92E-08 & 0.1 \\
\hline
\end{tabular}

Owing to all the factors listed earlier, which influence the quality of the production of cast rods, the process of homogenisation and further processing of rods, two cross-sections of the rods from two different alloys of the 6xxx group, were analysed in this study. From the cross-sections of the rods, samples for differential scanning calorimetry (DSC) were taken at three locations in order to determine the effect of inhomogeneity on the DSC curve. The samples after the DSC analysis were, furthermore, metallographically prepared and microstructure was analysed, where the actual chemical composition was analysed using a scanning electron microscope (SEM) and an energy dispersion spectrometer (EDS). 


\section{Materials and Methods}

Based on the chemical composition of investigated alloys, which correspond to the EN AW-6008 and EN AW-6060 standards given in Table 2, a simulation of the thermodynamically non-equilibrium solidification according to Scheil was performed using the Thermo-Calc software and the TCAL6 database.
In addition, DSC analysis was performed in order to determine the temperature changes and the thermal effects that occur during heating/melting and cooling/solidification of the investigated alloys. Experiments were carried out using the STA Jupiter 449C device from Netzsch by placing two identical corundum crucibles on the platinum sensor. In one crucible, the investigated sample, and in the other, a comparative (inert) sample was placed. The

Table 2: Chemical composition of investigated alloys according to EN-AW standards in wt.\%.

\begin{tabular}{ccccccccccc} 
Alloy & $\mathbf{S i}$ & $\mathbf{F e}$ & $\mathbf{C u}$ & $\mathbf{M n}$ & $\mathbf{M g}$ & $\mathbf{C r}$ & $\mathbf{Z n}$ & $\mathbf{T i}$ & $\mathbf{V}$ & $\mathbf{A l}$ \\
\hline 6008 & $0.50-0.90$ & 0.35 & 0.30 & 0.30 & $0.40-0.70$ & 0.30 & 0.20 & 0.10 & $0.05-0.20$ & Rest \\
\hline 6060 & $0.30-0.60$ & $0.10-0.30$ & 0.10 & 0.10 & $0.35-0.60$ & 0.05 & 0.15 & 0.10 & - & Rest \\
\hline
\end{tabular}

system was heated in a furnace according to the pre-programmed temperature program up to $720^{\circ} \mathrm{C}$. At this temperature, it was kept for 10 minutes. Heating and cooling stages were carried out at a constant rate of $10 \mathrm{~K} / \mathrm{min}$. The test was performed in a protective atmosphere of argon Ar 6.0. During the measurement, the apparatus measured the temperature, the difference in temperatures between the investigated and the comparative samples and the time. DSC analysis was carried out on cast samples taken from the centre, on D/4 and on the edge of the cross-section of the rod. The samples were cut from the cross-section of the rod and turning at a diameter of $4.5 \mathrm{~mm}$ and a height of $4 \mathrm{~mm}$, which were inserted into the device where analysis was performed.

After the measurements, the heating and cooling DSC curves were plotted; the characteristic temperatures were determined from heating and cooling DSC curves, and the influence of the sampling site on the characteristic temperatures was analysed. After the DSC analysis, the samples were metallographically prepared and photographed using a BX61 light microscope with the purpose of analysing the influence of the sampling site from the cross-section of the rod on the formation and distribution of microstructural components. Furthermore, using the SEM Jeol JSM-7600F and EDS analyzer NCA Oxford 350 EDS SDD, the chemical composition of all samples after DSC analysis was analysed, and the homogeneity of the chemical composition in the intersection of the rod was analysed.

\section{Results and Discussion}

Figure 1a shows the calculated cooling curve of the alloy EN AW-6008 (Scheil's model), with the dotted line showing the course of equilibrium solidification. In this alloy, according to the calculation, in the microstructure, the primary $\alpha$-Al, eutectic $\alpha-\mathrm{Al}+\mathrm{Al}_{15} \mathrm{Si}_{2} \mathrm{M}_{4}$ and eutectic $\alpha-\mathrm{Al}+\mathrm{Al}_{15} \mathrm{Si}_{2} \mathrm{M}_{4}+\mathrm{Al}_{9} \mathrm{Fe}_{2} \mathrm{Si}_{2}$ phases can be expected, while at a lower temperature (approximately $568^{\circ} \mathrm{C}$ ), the eutectic phases $\mathrm{Al}_{18} \mathrm{Fe}_{2} \mathrm{Mg}_{7} \mathrm{Si}_{10}$ and $\mathrm{Mg}_{2} \mathrm{Si}$ can solidify. Non-equilibrium solidification begins at $654^{\circ} \mathrm{C}$ and ends at $558^{\circ} \mathrm{C}$. In the following, the Scheil's model of non-equilibrium solidification taking into account the large diffusion coefficients of the elements of silicon and magnesium is calculated (Figure 1b). In this case, only three phases are obtained: $\alpha$-Al, eutectic $\alpha$ - $\mathrm{Al}+\mathrm{Al}_{15} \mathrm{Si}_{2} \mathrm{M}_{4}$ and eutectic $\alpha-\mathrm{Al}+\mathrm{Al}_{8} \mathrm{Fe}_{2} \mathrm{Si}$. The solidification starts at $T_{L}=654^{\circ} \mathrm{C}$ and ends at $T_{S}=603^{\circ} \mathrm{C}$.

Figure 2 shows the calculated cooling curve of the alloy EN AW-6060 (Scheil's model). In this alloy, the primary crystals of $\alpha-\mathrm{Al}$, eutectic $\alpha-\mathrm{Al}+\mathrm{Al}_{13} \mathrm{Fe}_{4}$ and eutectic $\alpha-\mathrm{Al}+\mathrm{Al}_{13} \mathrm{Fe}_{4}+\mathrm{Al}_{8} \mathrm{Fe}_{2} \mathrm{Si}$ can be found in the microstructure; the phase 

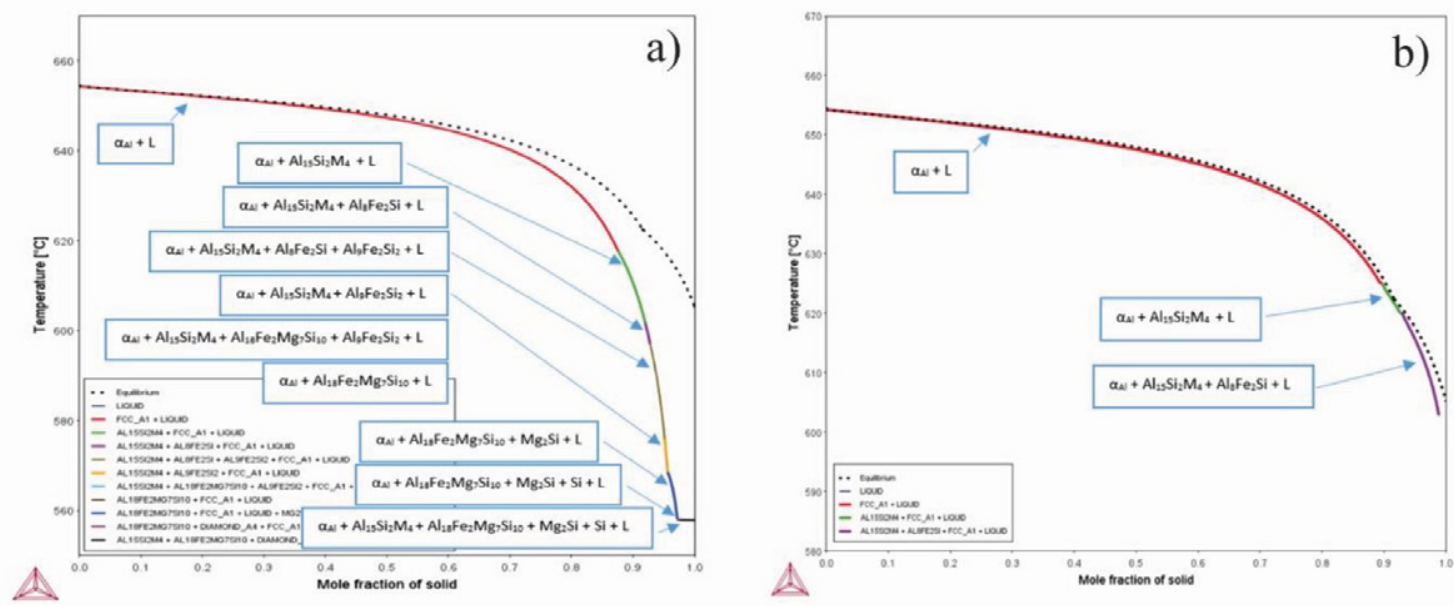

Figure 1: The cooling curve of the non-equilibrium solidification of the alloy EN AW-6008 without considering the diffusion (a) and taking into account the larger diffusion coefficients of the elements of silicon and magnesium (b).
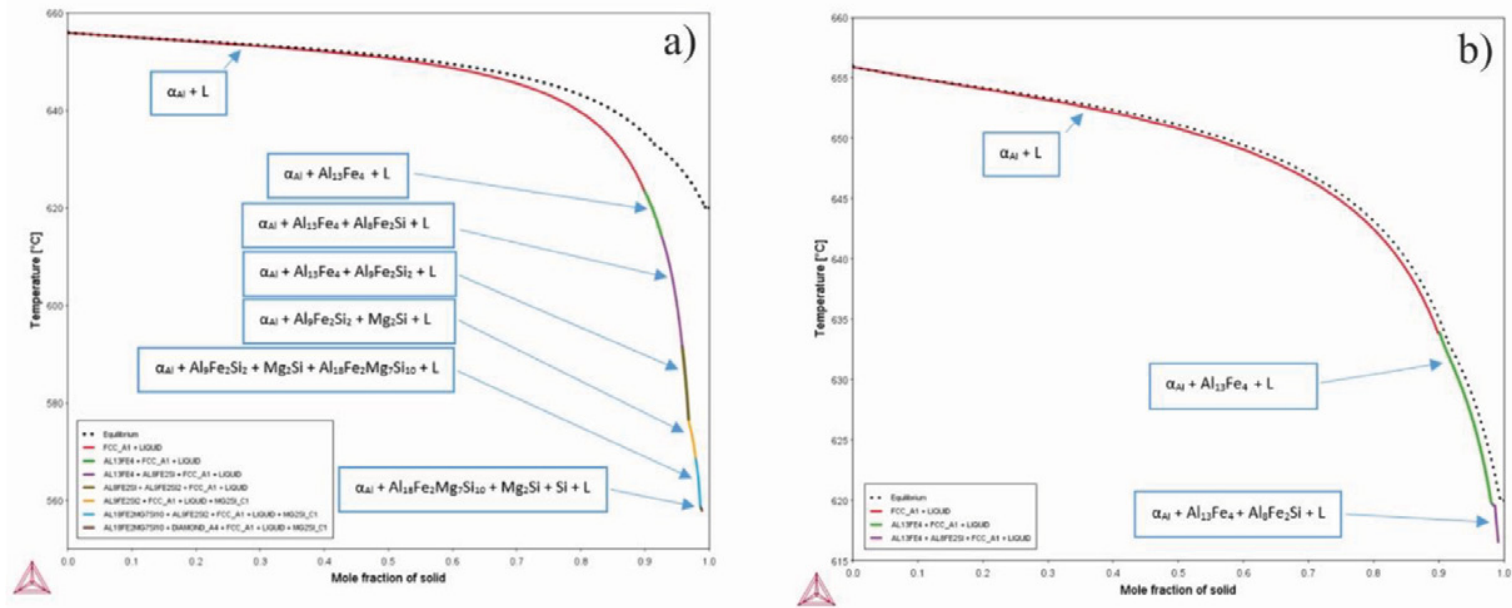

Figure 2: The cooling curve of the non-equilibrium solidification of the alloy EN AW-6060 without considering the diffusion (a) and taking into account the larger diffusion coefficients of the elements of silicon and magnesium (b).

$\mathrm{Al}_{8} \mathrm{Fe}_{2} \mathrm{Si}$ is transformed into the phase $\mathrm{Al}_{9} \mathrm{Fe}_{2} \mathrm{Si}_{2}$ also at a lower temperature, the eutectic phases $\mathrm{Al}_{18} \mathrm{Fe}_{2} \mathrm{Mg}_{7} \mathrm{Si}_{10}$ and $\mathrm{Mg}_{2} \mathrm{Si}$ can solidify. Non-equilibrium solidification begins at $656^{\circ} \mathrm{C}$ and ends at $557^{\circ} \mathrm{C}$. Figure $2 \mathrm{~b}$ shows Scheil's model of non-equilibrium solidification taking into account the large diffusion coefficients of silicon and magnesium. In this case, only three phases are obtained in the non-equilibrium curve: $\alpha$-Al, eutectic $\alpha-\mathrm{Al}+\mathrm{Al}_{13} \mathrm{Fe}_{4}$ and eutectic $\alpha-\mathrm{Al}+\mathrm{Al}_{13} \mathrm{Fe}_{4}+\mathrm{Al}_{8} \mathrm{Fe}_{2} \mathrm{Si}$. The solidification starts at $T_{L}=656^{\circ} \mathrm{C}$ and ends at $T_{S}=616^{\circ} \mathrm{C}$.
At the heating DSC curve, the $\mathrm{Al}_{3} \mathrm{Ti}$ and AlMg- $\beta$ phases at the temperature of $233.2^{\circ} \mathrm{C}$ and $282.4^{\circ} \mathrm{C}$, respectively, presumably precipitate (Figure $3 \mathrm{~b}$ ), which was verified by thermodynamic calculations/simulations of equilibrium solidification and is a consequence of the supersaturated solid solution of the pre-hardened alloy. At $601.0^{\circ} \mathrm{C}$, the eutectic $\alpha-\mathrm{Al}+\mathrm{Al}_{8} \mathrm{Fe}_{2} \mathrm{Si}$ melts, which represents a solidus temperature, and at a temperature of $609.6^{\circ} \mathrm{C}$, the eutectic $\alpha-\mathrm{Al}+\mathrm{Al}_{15} \mathrm{Si}_{2} \mathrm{M}_{4}$ melts with respect to the Scheil's calculation in Figure 1. Furthermore, at $646.8^{\circ} \mathrm{C}$, melting of primary 
a) $\mathrm{DSC} /(\mathrm{mW} / \mathrm{mg})$

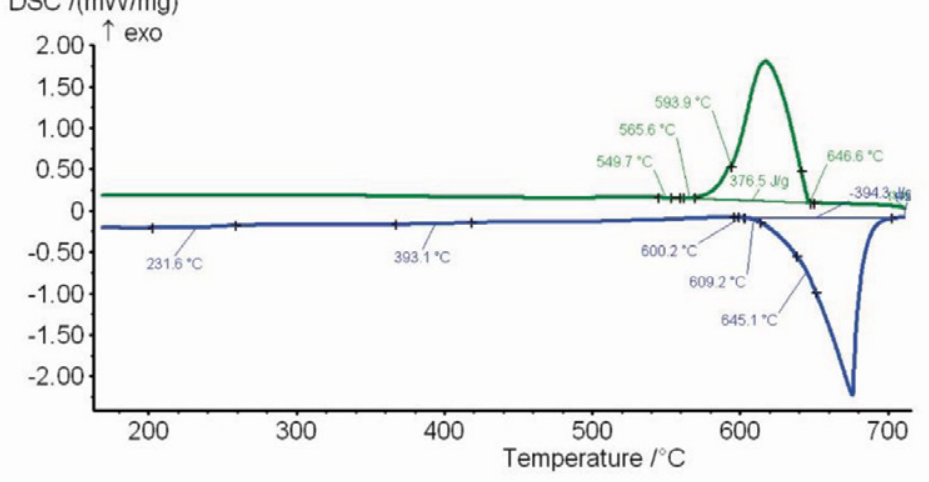

b) $D S C /(m W / m g)$

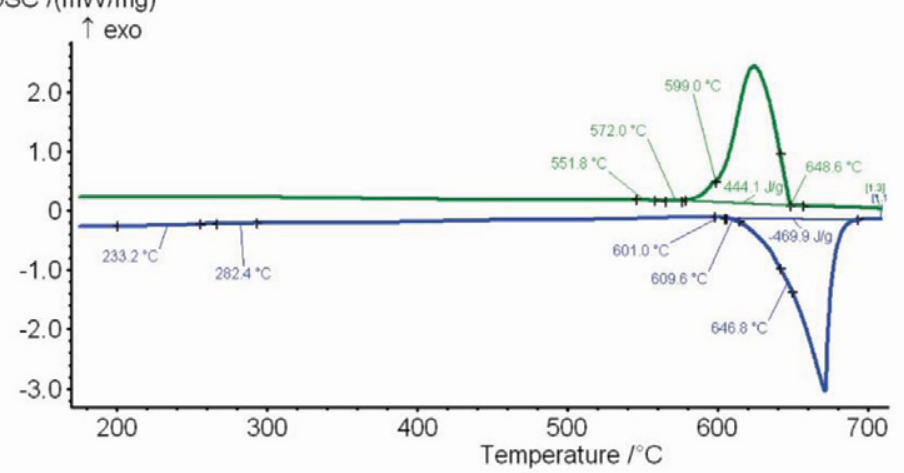

c) $D S C /(\mathrm{mW} / \mathrm{mg})$

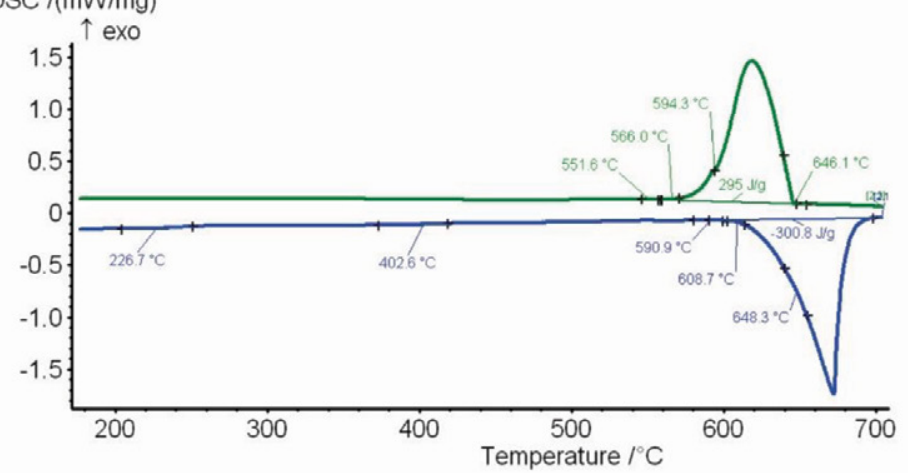

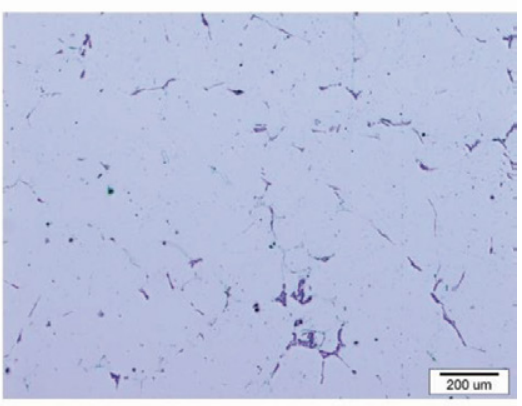
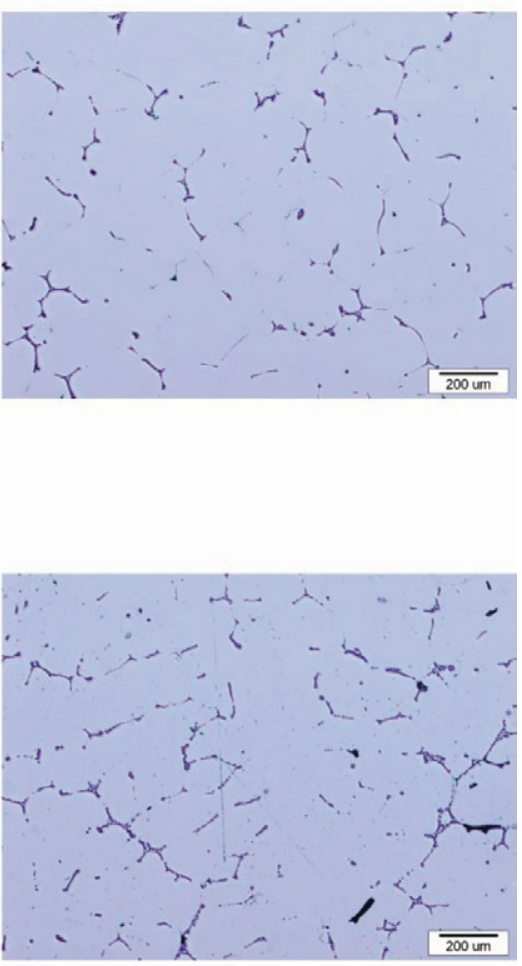

Figure 3: Heating (blue) and cooling (green) DSC curves of the samples 6008_centre (a), 6008_D/4 (b) and 6008_edge (c) with marked characteristic temperatures and corresponding microstructure images.

$\alpha$-Al crystals is observed. During cooling, at a temperature of $648.6^{\circ} \mathrm{C}$, the primary $\alpha$ - $\mathrm{Al}$ solidifies; at a temperature of $599.0^{\circ} \mathrm{C}$, eutectic $\alpha-\mathrm{Al}+\mathrm{Al}_{15} \mathrm{Si}_{2} \mathrm{M}_{4}$ and at a temperature of $572^{\circ} \mathrm{C}$, eutectic $\alpha$-Al $+\mathrm{Al}_{8} \mathrm{Fe}_{2} \mathrm{Si}$. At $551.8^{\circ} \mathrm{C}$, most likely the $\mathrm{Si}_{2} \mathrm{~V}$ eutectic phase solidifies (named as $\mathrm{CrSi}_{2}$ in the TC calculation).

Similar transitions are also observed on DSC curves of samples taken from the centre and edge of the cross-section of the rod, except that the temperatures slightly differ (Figure 3a and c). When comparing the curves, distinct differences are observed, which probably suggests an inhomogeneous chemical composition in the cross-section of the rod (Figure 4). This is also confirmed by microstructural images after DSC analysis at various sites. The density of microstructural components is much higher 

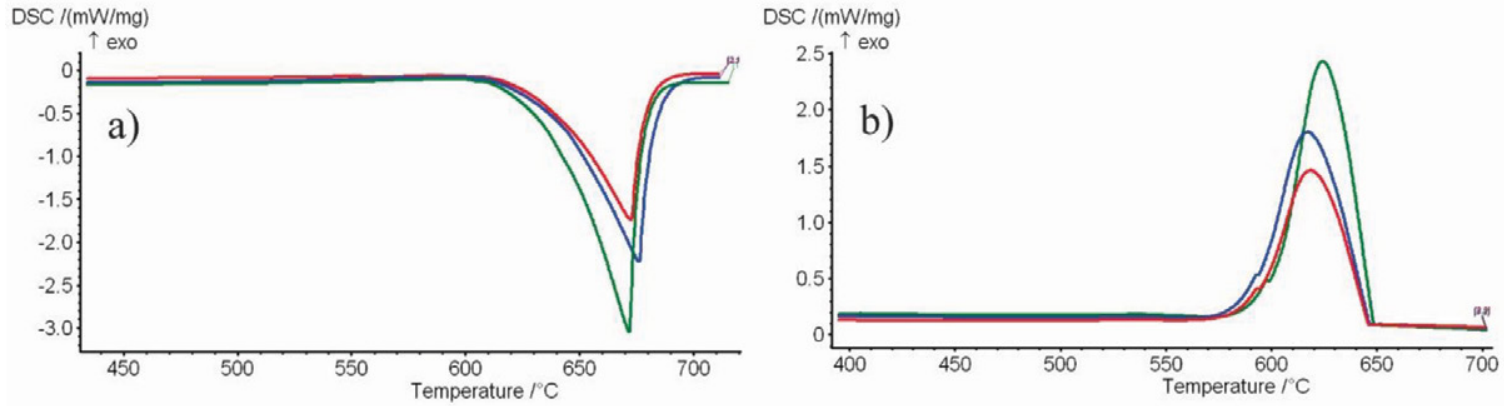

Figure 4: Comparison of heating (a) and cooling (b) DSC curves of EN AW-6008 alloy from different places of the rod: centre (blue), D/4 (green) and edge (red).

a) $\mathrm{DSC} /(\mathrm{mW} / \mathrm{mg})$
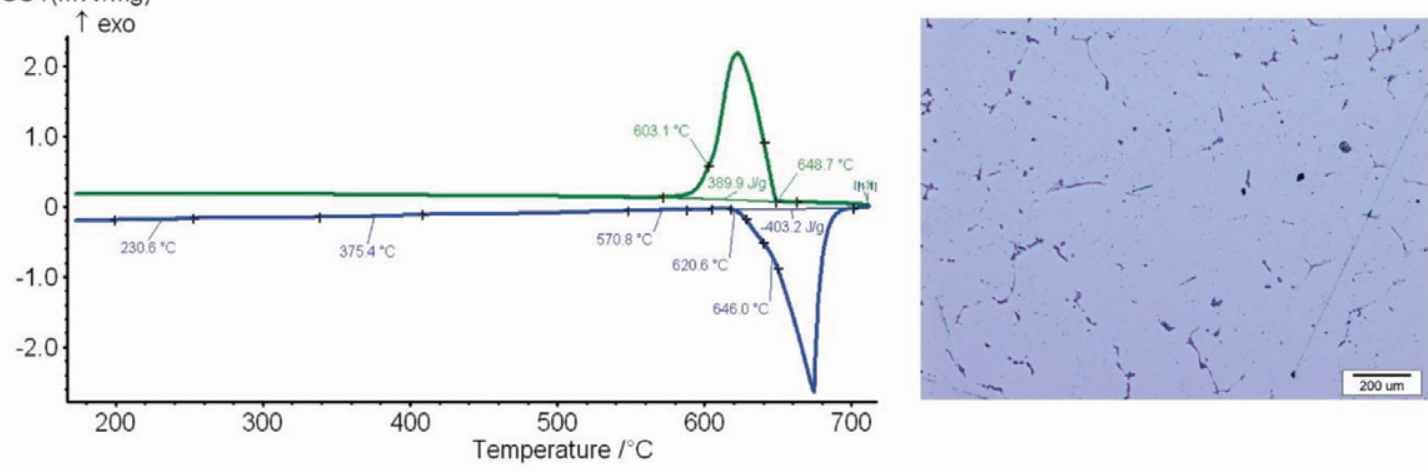

b) $\mathrm{DSC} /(\mathrm{mW} / \mathrm{mg})$
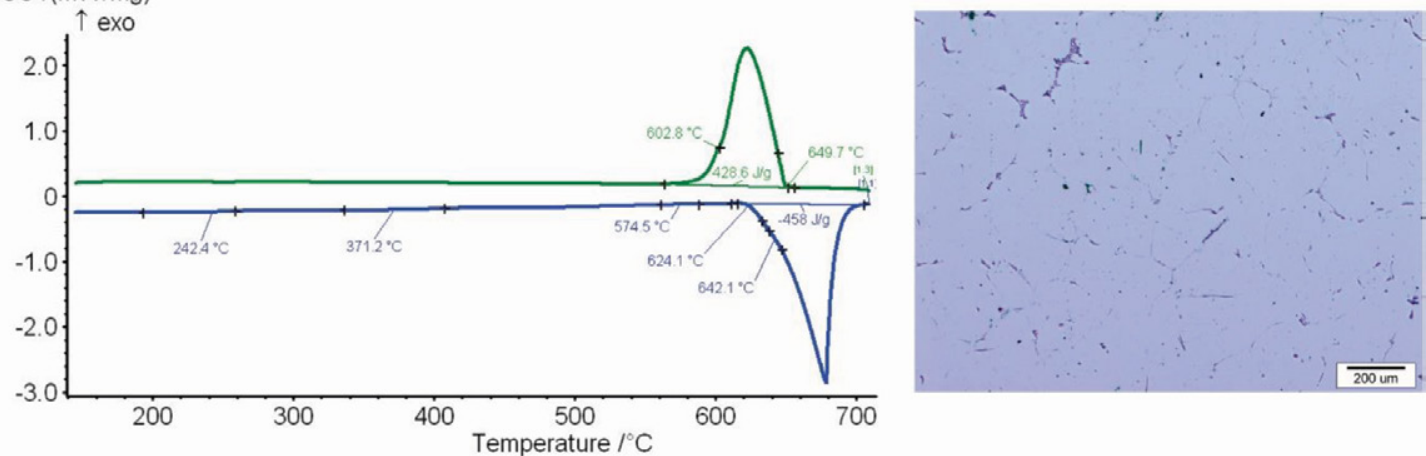

c) $\mathrm{DSC} /(\mathrm{mW} / \mathrm{mg})$
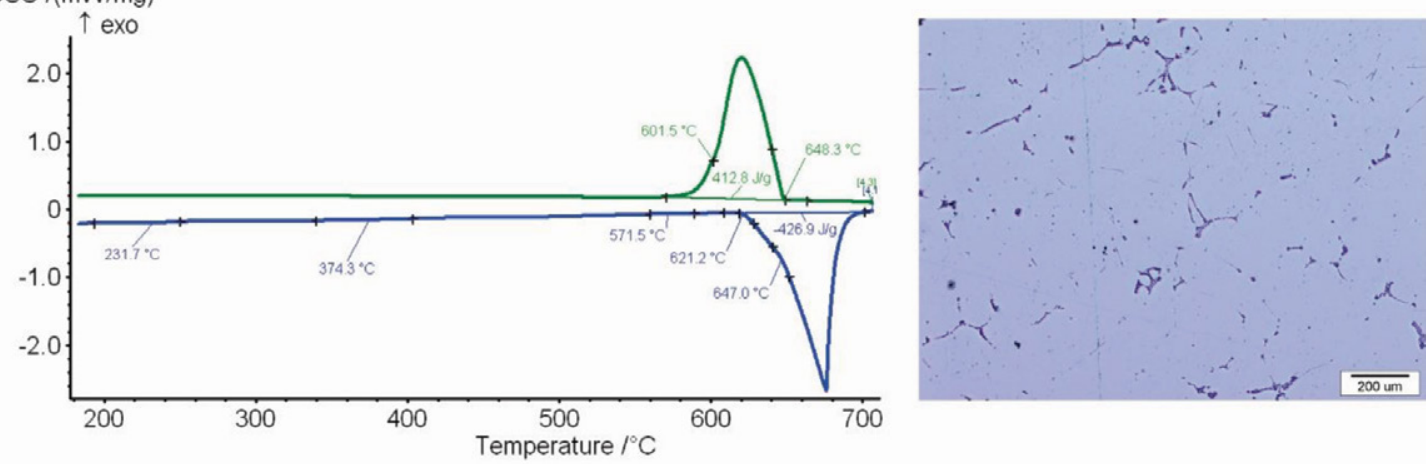

Figure 5: Heating (blue) and cooling (green) DSC curves of the sample 6060_centre (a), sample 6060_D/4 (b) and sample 6060 edge (c) with marked characteristic temperatures and corresponding microstructure images. 

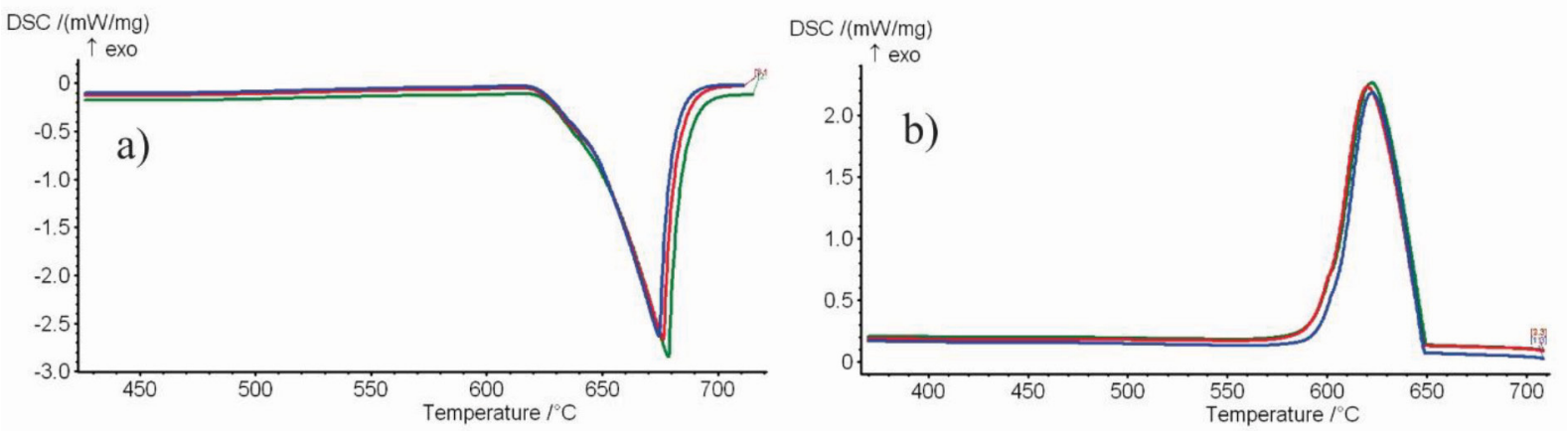

Figure 6: Comparison of heating (a) and cooling (b) DSC curves of EN AW-6060 alloy from different places of the rod: centre (blue), D/4 (green) and edge (red).

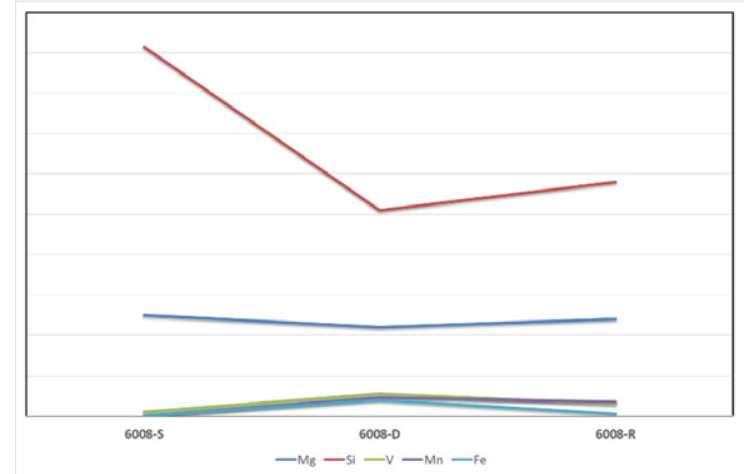

Figure 7: EDS analysis of samples from the alloy EN AW-6008 taken from the cross-section of the rod at D/4, centre and edge after the DSC analysis.

in the sample 6008_centre than in the sample 6008_edge, whereas the distribution of microstructure phases is most uniform in the sample 6008_D/4.

Figure 5 shows the heating and cooling DSC curves of samples from the EN AW-6060 alloy taken at three different locations with the accompanying microstructural images. At $574.5^{\circ} \mathrm{C}$, the eutectic $\alpha-\mathrm{Al}+\mathrm{Al}_{8} \mathrm{Fe}_{2} \mathrm{Si}$ begins to melt (according to the Scheil's calculation in Figure 2b), which represents the solidus temperature, and at a temperature of $624.1^{\circ} \mathrm{C}$, the eutectic $\alpha-\mathrm{Al}+\mathrm{Al}_{13} \mathrm{Fe}_{4}$ melts. Furthermore, at $642.1^{\circ} \mathrm{C}$, the melting of the primary crystals of $\alpha-\mathrm{Al}$ is observed. On the basis of the TC calculations of the equilibrium solidification, it can be concluded that the heating DSC curve leads to the precipitation of the phases $\mathrm{Al}_{15} \mathrm{Si}_{2} \mathrm{M}_{4}$ and $\mathrm{Mg}_{2} \mathrm{Si}$ at a temperature of $242.4^{\circ} \mathrm{C}$ and $371.2^{\circ} \mathrm{C}$, respectively. During cooling, the primary $\alpha$-Al (liquidus) solidifies at a temperature of

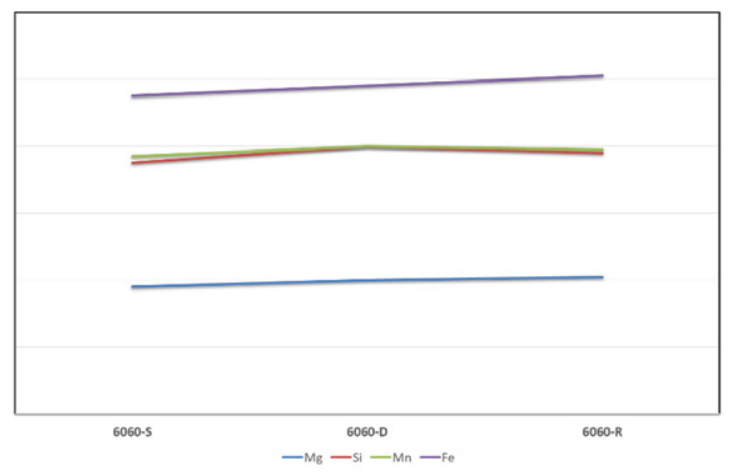

Figure 8: EDS analysis of samples from the alloy EN AW-6060 taken from the cross-section of the rod at D/4, centre and edge after the DSC analysis.

$649.7^{\circ} \mathrm{C}$ and eutectic with $\mathrm{Fe}$ phase $\left(\mathrm{Al}_{13} \mathrm{Fe}_{4}\right.$ or $\mathrm{Al}_{8} \mathrm{Fe}_{2} \mathrm{Si}$ ) solidifies at a temperature of $602.8^{\circ} \mathrm{C}$, depending on the ratio between Fe and Si. Similar changes are also observed on DSC analyses of samples taken from the centre (Figure 5a) and the edge (Figure $5 c$ ) of the cross-section of the rod, except that the temperatures differ slightly from one another. When comparing the heating (Figure 6a) and cooling (Figure 6b) of the DSC curves, it is observed that the curves are generally very similar, which indicates better homogeneity of the chemical composition across the cross-section of the rod. The higher homogeneity of the chemical composition and, consequently, of the microstructural components indicated by the results of the DSC analysis was confirmed also by the microstructural images shown next to the corresponding DSC analysis.

Figures 7 and 8 show the results of the EDS analysis on the samples after the DSC experi- 
ments confirming the preliminary conclusions; however, only the fluctuation of certain chemical elements is presented since the actual chemical composition of the investigated alloys could not be revealed. It can be seen that the chemical composition is not homogeneous in the cross-section of the cast rod. The largest deviations in the EN AW-6008 alloy are found in a silicon concentration, which varies by more than 0.5 wt.\%. Minor deviations are also found in concentrations of magnesium, vanadium, manganese and iron, which can be eliminated by appropriate homogenisation annealing.

Minor fluctuations in the chemical composition are shown by EDS analysis of the alloy EN AW-6060 (Figure 8), which was assumed already after the DSC analysis, where the DSC curves are very similar. The concentrations of magnesium, silicon, manganese and iron are slightly increased from the centre to the edge. EN AW-6060 alloy rods are fairly homogeneous in chemical composition already in the cast state.

\section{Conclusion}

The aim of this investigation was analysis of chemical composition homogeneity in the cross-sections of the rods produced from alloys of the 6xxx group. DSC analysis indicated non-homogeneity of the experimental alloys, whereas four reactions in case of EN AW-6008 alloy and two reactions in case of EN AW-6060 alloy could be expected, which corresponds to the Scheil's non-equilibrium calculations, where larger diffusion coefficients of the elements of silicon and magnesium were taken into account.

On the basis of the results presented earlier, it can be concluded that the alloy EN AW-6060 is already quite homogeneous in the cast state through the cross-section of the rod. The concentration of some elements slightly increases from the centre to the edge.

From the results of the analysis of the cross-section of the rod from the EN AW-6008 alloy, it is evident that the chemical composition is not homogeneous in the cross-section of the cast rod. The greatest deviations are observed in the concentration of silicon, which also fluctu- ates by more than $0.5 \mathrm{wt} . \%$. Minor deviations are also found in concentrations of magnesium, vanadium, manganese and iron, which can be eliminated by appropriate homogenisation annealing.

\section{Acknowledgements}

The work was co-financed by the Republic of Slovenia; the Ministry of Education, Science and Sport and the European Regional Development Fund. The work was carried out in the framework of the project Modelling of thermomechAnical pRocessing of The alumINium alloys for high quality products (MARTIN, Grant No.: C3330-18-952012).

\section{References}

[1] Zhong, H., Rometsch, P.A., Cao, L., Estrin, Y. (2016): The influence of $\mathrm{Mg} / \mathrm{Si}$ ratio and $\mathrm{Cu}$ content on the stretch formability of 6xxx aluminium alloys. Materials Science and Engineering: A, 651, pp. 688-697.

[2] Mukhopadhyay, P. (2012): Alloy Designation, Processing, and Use of AA5XXX Series Aluminium Alloys. ISRN Mettalurgy, 2012, pp. 1-16, doi: 10.5402/2012/165082.

[3] Jakobsen, J.V. (2016): Microstructure and Mechanical Properties of welded AA6082 Aluminum Alloys. Master Thesis. Trondheim, $89 \mathrm{p}$.

[4] Sha, G., O’Reilly, K., Cantor, B., Worth, J., Hamerton, R. (2001): Growth related metastable phase selection in a 6xxx series wrought $\mathrm{Al}$ alloy. Materials Science and Engineering: A, Elsevier, 304-306, pp. 612-616.

[5] Substances and Technologies [online]. SubsTech [cited 7/28/2012]. Available on: https://www.google.si/\#q=SubsTech.+Classification+of.

[6] Zhong, H., Rometsch, P.A., Estrin, Y. (2014): Effect of alloy composition and heat treatment on mechanical performance of 6xxx aluminum alloys. Transactions of Nonferrous Metals Society of China, 24(7), pp. 2174-2178.

[7] Totten, G.E., Mackenzie, D.S. (2016): ASM Handbook vol. 4E; Heat Treating of Nonferrous Alloys. ASM International, pp. 32-37.

[8] Kammer, C. (1999): Aluminium handbook vol. 1: Fundamentals and Materials. Aluminium-Zentrale e.V.: Germany, 718 p. 
[9] Mackenzie, A.S., Totten, G.E. (2003): Handbook of Aluminium vol. 1: Physical Metallurgy and processes. Marcel Dekker, Inc.: New York, 1310 p.

[10] Van Horn, K.R. (1967): Aluminium vol. 1: Properties, physical metallurgy and phase diagrams. Metals Park: American Society for Metals, 2521p.

[11] Tohru, A., Gordon Baker, M. (1991): Handbook, A.S.M. Volume 4, Heat Treating. ASM International, 1960 p.

[12] Zolotorevsky, V.S., Glazoff, M.V., Belov, N.A. (2007): Casting aluminium alloys. Elsevier: Oxford, pp. 184-185.

[13] Lise Dons A. (2001): The Alstruc homogenization model for industrial aluminum alloys. Journal of light Metals 1, pp. 133-149.

[14] Gale, W.F., Totemeier T.C. (2004): Smithells Metals Reference Book: Eighth Edition, Elsevier.

[15] Hood, G.M. (1969): The Diffusion of Iron in Aluminium. Chalk River Nuclear Laboratories, pp. 305-328.

[16] Hood, G.M., Schultz, R.J. (1970): The Diffusion of Manganese in Aluminium. Chalk River Nuclear Laboratories, pp. 1479-1489.

[17] Paccagnella, A., Ottaviani, G., Fabbri, P., Ferla, G., Queirolo, G. (1985): Silicon Diffusion in Aluminium. Thin Solid Films, 128(3-4), pp. 217-232. 